\section{Application of fungicides and urea for control of ash dieback}

\author{
Tine Hauptman (1), Franci Aco Celar ${ }^{(2)}$, Maarten de Groot ${ }^{(1)}$, \\ Dušan Jurc ${ }^{(1)}$
}

Ash dieback is caused by a highly pathogenic fungus Hymenoscyphus pseudoalbidus (anamorph Chalara fraxinea). Possibilities for disease control are limited, and treatment of fallen leaf debris to prevent sporulation of the pathogen is one of the possible options to control the disease. In some cases chemical treatments could be used, but data on effective chemical agents for control of the ash dieback are lacking. The purpose of this study was to examine the effect of different chemical fungicides and urea on the pathogen. Out of eight tested fungicides, mycelial growth in Petri plates as well as development of $H$. pseudoalbidus apothecia on ash leaf petioles were most efficiently inhibited by carbendazim. Urea also proved to be effective in prevention of apothecial formation. In addition to inhibition of the pathogen, urea accelerates the degradation of treated leaf debris. Therefore, the use of urea for treatment of infected ash leaf debris could be more effective than the use of fungicides and also more environmentally acceptable.

Keywords: Hymenoscyphus pseudoalbidus, Chemical Control, Mycelial Growth, Leaf Petioles, Apothecia Formation

\section{Introduction}

Ash dieback is an emerging fungal disease caused by the ascomycete Hymenoscyphus pseudoalbidus Queloz et al. (2011), anamorph Chalara fraxinea Kowalski (2006). This highly pathogenic fungus was most likely introduced from the Far East (Zhao et al. 2012). The first symptoms of the disease were observed in Poland in 1992, and since the pathogen has spread throughout Europe (Timmermann et al. 2011, Pautasso et al. 2013). Common ash (Fraxinus excelsior L.) and narrow-leaved ash ( $F$. angustifolia Vahl.) are European ash species the most heavily affected by the pathogen (Kirisits et al. 2009, 2010, Gross et al. 2014), although some introduced ash species could also be attacked (Drenkhan \& Hanso 2010).

Control of the ash dieback is hardly possible in areas where the disease is already established (Gross et al. 2014). However, proper control measures should still be taken to prevent or at least to slow down further spread of the pathogen (Pautasso et al.

2013), or to eradicate the pathogen at locations where this is still possible (relatively small, spatially limited and recently infected areas). Furthermore, the protection of individual high-value ash trees should also be often provided. Chemical treatment may be one of the options in some cases, but data on effective chemical agents for control of the ash dieback pathogen are lacking.

Ascospores that develop in apothecia on infected ash leaf debris from the previous year are the major source of new infections (Gross et al. 2012, 2014). Leaf debris from the previous year represents an inoculum source for some other well-known tree diseases. Good examples are cherry leaf spot caused by Blumeriella jaapii (Rehm) Arx and apple scab caused by Venturia inaequalis (Cook) Wint. For control of both mentioned diseases, urea treatments of the infected leaves are used to reduce pathogen sporulation (Sutton et al. 2000, Bengtsson et al. 2006, Green et al. 2006). Thus, removal of the infected ash leaf debris (if possible) or

(1) Department of Forest Protection, Slovenian Forestry Institute, Večna pot 2, SI-1000 Ljubljana (Slovenia); (2) Agronomy Department, Biotechnical Faculty, University of Ljubljana, Jamnikarjeva 101, SI-1000 Ljubljana (Slovenia)

(a) Tine Hauptman (tine.hauptman@gozdis.si)

Received: Feb 20, 2014 - Accepted: May 07, 2014

Citation: Hauptman T, Celar FA, de Groot M, Jurc D, 2015. Application of fungicides and urea for control of ash dieback. iForest 8: 165-171 [online 2014-08-13] URL:

http: / / www.sisef.it/iforest/contents/?id=ifor1272-008

Communicated by: Alberto Santini treatment of the debris to prevent sporulation of $H$. pseudoalbidus could therefore be regarded as potential control measures (Cooke et al. 2013).

The main aim of this study was to examine the effect of eight different fungicides that are effective against different pathogens of the Helotiales order as well as the effect of urea on mycelial growth in Petri plates and development of $H$. pseudoalbidus apothecia on fallen ash leaf petioles.

\section{Materials and Methods}

\section{H. pseudoalbidus isolates used in testing}

Four Slovenian isolates of Hymenoscyphus pseudoalbidus were used in this study (Tab. 1). Isolates were previously obtained from necrotic $F$. excelsior wood samples and stored in the culture collection of the Laboratory for Forest Protection at the Slovenian Forestry Institute (ZLVG). The selected isolates were of different morphology in culture and represented different geographical regions of the country. Three weeks before treatment experiments (preliminary testing was planned on July $13^{\text {th }}, 2010$, and the main testing on August $26^{\text {th }}, 2010$ ), all four isolates (ZLVG 176, ZLVG 177, ZLVG 200 and ZLVG 213) were sub-cultured on malt extract agar (MEA; 2\% malt extract, 1.5\% agar, Difco) in 70-mm diameter Petri dishes and incubated at $22^{\circ} \mathrm{C}$ in the dark.

\section{Testing growth of $H$. pseudoalbidus cultures on fungicide- and urea-} amended media

Eight different fungicides (Tab. 2) were used in a preliminary testing. The recommended fungicide concentrations for a field application given by their manufacturers were converted into values suitable for our experiment using area as a conversion factor (from hectares of field to square centimeters of Petri dishes). Five fungicides that proved to be most effective in the preliminary testing were selected for further investigations (in the main experiment).

For each tested fungicide, $100 \mathrm{ml}$ (in the preliminary testing) or $1000 \mathrm{ml}$ (in the main experiment) of stock solution was prepared by adding $1 \mathrm{ml}$ (for liquids) or $1 \mathrm{~g}$ (for solid materials) of a commercial product to a sterile distilled water and final concentrations used in the experiments were obtained by serial dilution. In the preliminary testing, ten milliliters of each of the prepared solution were added to $490 \mathrm{ml}$ of potato dextrose agar (3.9\% PDA, Difco) to make the final concentrations of the active ingredients (Tab. 2). The temperature of the medium at the time of adding the fungicide was approximately $50^{\circ} \mathrm{C}$.

In the main test, the five best-performing 
Tab. 1 - Information on Hymenoscyphus pseudoalbidus isolates used in the fungicide/urea testing activities.

\begin{tabular}{|c|c|c|c|c|}
\hline $\begin{array}{l}\text { Isolate } \\
\text { name }\end{array}$ & $\begin{array}{l}\text { Sampling } \\
\text { location }\end{array}$ & $\begin{array}{l}\text { Isolation } \\
\text { date }\end{array}$ & $\begin{array}{c}\text { Isolated } \\
\text { by }\end{array}$ & $\begin{array}{c}\text { GenBank } \\
\text { accession number }\end{array}$ \\
\hline ZLVG 176 & $\begin{array}{l}\text { Negova } \\
46^{\circ} 36^{\prime} 26^{\prime} \text { N }, 15^{\circ} 56^{\prime} 06^{\prime \prime} \mathrm{E}\end{array}$ & 06.04 .2007 & N. Ogris & HM140827 \\
\hline ZLVG 177 & $\begin{array}{l}\text { Ribnica } \\
45^{\circ} 41^{\prime} 39^{\prime \prime} \mathrm{N}, 14^{\circ} 46^{\prime} 10^{\prime \prime} \mathrm{E}\end{array}$ & 26.07.2007 & N. Ogris & HM140830 \\
\hline ZLVG 200 & $\begin{array}{l}\text { Sabansko bukovje } \\
46^{\circ} 00^{\prime} 12^{\prime \prime} \mathrm{N}, 15^{\circ} 02^{\prime} 30^{\prime \prime} \mathrm{E}\end{array}$ & 01.06 .2007 & N. Ogris & HM140828 \\
\hline ZLVG 213 & $\begin{array}{l}\text { Kranj } \\
46^{\circ} 14^{\prime} 29^{\prime \prime} \mathrm{N}, 14^{\circ} 21^{\prime} 29^{\prime \prime} \mathrm{E}\end{array}$ & 01.08 .2008 & N. Ogris & HM140829 \\
\hline
\end{tabular}

fungicides (BAVISTIN FL, BRAVO 500 SC, MERPAN 80 WDG, OCTAVE and THIRAM 80 WG - Tab. 2) were tested at concentrations of $0.1,1.0$ and $10.0 \mathrm{mg}$ of active ingredient per liter of $3.9 \%$ PDA growth medium. Urea-amended medium was prepared by a similar procedure: $1000-\mathrm{ml}$ stock solution was prepared by adding $10 \mathrm{~g}$ of urea (Urea for analysis, Carlo Erba ${ }^{\circledR}$ ) to sterile distilled water, and the working concentrations were adjusted to $0.5,1.0,2.5,5.0$ and $10.0 \mathrm{~g}$ of urea per liter of $3.9 \%$ PDA growth medium. In both experiments, control plates were prepared by adding $10 \mathrm{ml}$ of sterile distilled water to $490 \mathrm{ml}$ of the $3.9 \%$ PDA growth medium.

Petri dishes with fungicide- and ureaamended PDA and control plates were inoculated with 6-mm mycelium plugs taken from the edge of three-week-old $H$. pseudoalbidus colonies. The study was performed with five replicates of four different isolates (Tab. 1). All inoculated plates were incubated at $22^{\circ} \mathrm{C}$ in the dark. The colony diameters were measured 14 days post-inoculation with a ruler to an accuracy of $0.5 \mathrm{~mm}$. The diameter for each colony was calculated as an average of two measurements made along perpendicular axes reduced by $6 \mathrm{~mm}$ (the diameter of the inoculum plug). To better understand the efficacy of each chemical, fungal growth on fungicide- and urea-amended plates was presented relative to the fun- gal

growth on control plates. The mean diameter of every colony of a particular isolate on fungicide- and urea-amended plate was therefore divided by the mean colony diameter of the same isolate on control plates.

\section{Apothecia development on treated ash leaf petioles}

Ash leaf petioles were collected under dieback-infected common ash trees in Ljubljana (Slovenia - $46^{\circ} 03^{\prime} 11^{\prime \prime} \mathrm{N}, 14^{\circ} 29^{\prime} 15^{\prime \prime}$ E) on November $25^{\text {th }}, 2010$, and stored at 6 ${ }^{\circ} \mathrm{C}$ in the dark until the treatment experiment planned on January $15^{\text {th }}, 2011$. To prepare $500-\mathrm{ml}$ of fungicide or urea solutions for the petiole treatments, ten milliliters of the respective stock solution was added to $490 \mathrm{ml}$ of sterile distilled water to make the final concentrations of fungicidal active ingredients of $0.1,1.0$ and $10.0 \mathrm{mg} / \mathrm{l}$ and the final concentrations of urea of 5,10 and $20 \mathrm{~g} / \mathrm{l}$. Additionally, carbendazim and prochloraz were tested at concentrations of $0.01 \mathrm{mg} / \mathrm{l}$, while captan, thiram and chlorothalonil were also tested at $100 \mathrm{mg} / \mathrm{l}$.

Leaf petioles ( 25 per treatment) were dipped in the prepared fungicide and urea solutions in 22-cm glass Petri dishes for 24 hours. In control treatments, leaf petioles were dipped in $500 \mathrm{ml}$ of sterile distilled water. During the treatments, Petri dishes with leaf petioles were placed by a window on the laboratory desk at room temperature (ap-

Tab. 2 - Data on fungicides used in preliminary testing. (*): mg of active ingredient per liter of $3.9 \%$ PDA growth medium.

\begin{tabular}{|c|c|c|c|c|}
\hline $\begin{array}{l}\text { Commercial prod- } \\
\text { uct }\end{array}$ & $\begin{array}{l}\text { Active } \\
\text { ingredient }\end{array}$ & $\begin{array}{l}\text { Share of } \\
\text { active } \\
\text { ingredient } \\
(\%)\end{array}$ & Manufacturer & $\begin{array}{l}\text { Concentration of } \\
\text { active ingredient } \\
\text { used in preliminary } \\
\text { testing* }(\mathrm{mg} / \mathrm{l})\end{array}$ \\
\hline BAVISTIN FL & Carbendazim & $50 \mathrm{w} / \mathrm{v}$ & BASF SE & 6.0 \\
\hline BRAVO $500 \mathrm{SC}$ & Chlorothalonil & $51.5 \mathrm{w} / \mathrm{v}$ & SYNGENTA & 35.5 \\
\hline MERPAN 80 WDG & Captan & $80 \mathrm{w} / \mathrm{w}$ & $\begin{array}{l}\text { MEKHTESHIM- } \\
\text { AGAN }\end{array}$ & 55.2 \\
\hline MYTHOS & Pyrimethanil & $30 \mathrm{w} / \mathrm{v}$ & BASF SE & 17.4 \\
\hline $\begin{array}{l}\text { ROVRAL } \\
\text { AQUAFLO }\end{array}$ & Iprodione & $50 \mathrm{w} / \mathrm{v}$ & BASF SE & 26.0 \\
\hline OCTAVE & Prochloraz & $50 \mathrm{w} / \mathrm{w}$ & BASF SE & 4.5 \\
\hline TELDOR SC 500 & Fenhexamid & $50 \mathrm{w} / \mathrm{v}$ & BAYER SC & 17.5 \\
\hline THIRAM $80 \mathrm{WG}$ & Thiram & $80 \mathrm{w} / \mathrm{w}$ & TAMINCO & 55.2 \\
\hline
\end{tabular}

prox. $21^{\circ} \mathrm{C}$ ). All leaf petioles were air dried (non-sterile conditions) after the treatments for four hours and subsequently incubated on wet paper towels in 22-cm glass Petri dishes at temperatures between 17 and 23 ${ }^{\circ} \mathrm{C}$. The paper towels were changed weekly and moistened to assure constantly high humidity. To provide sufficient light conditions for the development of apothecia, Petri dishes with treated leaf petioles were placed on a table by a window. On February $18^{\text {th }}, 2011$ (34 days from the beginning of the experiment), all leaf petioles were examined with an Olympus SZX12 stereo microscope. All developed apothecia were counted. Apothecial disc surface areas were measured using a Nikon DS-Fil camera and NIS-Elements BR 2.3 computer software (Nikon). At least 200 apothecia were measured per each treatment (10 randomly chosen apothecia per petiole). All apothecial discs were measured when less than 200 apothecia per treatment or less than 10 apothecia per leaf petiole have developed.

For the repeated urea treatment, ash leaf petioles were collected on April $20^{\text {th }}, 2011$, at the same site as in November 2010, and stored at $6{ }^{\circ} \mathrm{C}$ in the dark until their treatment on April 28 $8^{\text {th }}, 2011$. Treatment procedure and conditions were the same as on January $15^{\text {th }}, 2011$, but tested urea concentrations $(0.5,1.0,2.5,5.0$ and $10.0 \mathrm{~g}$ per liter of solution) were different. After-treatment procedure was also the same as in January, 2011, except that incubation temperature was a little higher $\left(21-25^{\circ} \mathrm{C}\right)$. The treated petioles were regularly checked, and the final counting of all developed apothecia was conducted on June $13^{\text {th }}, 2011$ (45 days from the beginning of the experiment). Microscope Olympus BX 51 was used to examine fruiting bodies that developed on leaf petioles.

\section{Statistical analysis}

The effect of concentration of active ingredient and a given fungal isolate on a relative diameter of the treated cultures and their interaction were tested with a linear mixed model fitted by REML with a variance structure for concentration (Zuur et al. 2009). The concentration was used as a random effect. The effect of active ingredient and its concentration, and the effect of their interaction on a number and surface area of the apothecial discs were tested with a linear model fitted by REML, including a combined variance structure for the concentration and the active ingredient. The effect of urea concentration and a given isolate, and the effect of their interaction on a relative diameter of cultures were tested with a linear model fitted by REML, including a variance structure for the concentration and the isolate. The comparisons between the explanatory variables for all the tests were performed with the 
Games-Howell post-hoc test (Quinn \& Keough 2002). All analyses were performed with the statistical program R (R Development Core Team 2011).

\section{Results}

Effect of fungicides on in vitro growth of $H$. pseudoalbidus mycelium

Five of the eight fungicides used in the preliminary testing (Tab. 2) fully prevented the growth of $H$. pseudoalbidus mycelium on fungicide-amended agar plates. These fungicides included ones with active ingredients carbendazim, prochloraz, captan, thiram and chlorothalonil. Less effective were fungicides with active ingredients pyrimethanil, iprodione and fenhexamid. Mean H. pseudoalbidus colony diameter on iprodion-amended medium was by $87 \%$ smaller than that on control plates. Pyrimethanil and fenhexamid caused a reduction of mean colony diameter compared to control plates by 49 and $12 \%$, respectively.

In the main experiment, significant differences $(\mathrm{F}=118.85, \mathrm{p}<0.001)$ were found between the relative diameters of $H$. pseudoalbidus cultures treated with five different active ingredients that proved the most effective in the preliminary testing (Tab. 3). Carbendazim, prochloraz and chlorothalonil have significantly $(\mathrm{p}<0.05)$ reduced growth of $H$. pseudoalbidus at all tested concentrations. The most effective active ingredient was carbendazim, as no fungal growth was observed at any of the three tested concen- trations, while prochloraz and chlorothalonil were slightly less effective (Tab. 3). Captan was the least effective of the all five tested active ingredients. Two lowest concentrations of the captan $(0.1$ and $1 \mathrm{mg} / \mathrm{l})$ have even accelerated the growth of all four $H$. pseudoalbidus isolates (Tab. 3). A significant $(\mathrm{p}<0.05)$ growth reduction compared to controls was observed only in plates with a $10.0 \mathrm{mg} / \mathrm{l}$ concentration of this active ingredient. Thiram reduced the growth of $H$. pseudoalbidus at all tested concentrations; however, the reduction was significant $(\mathrm{p}<$ 0.05 ) only at the highest concentrations of the fungicide (Tab. 3).

Significant interactions $(F=9.25, p<0.001)$ between the factors "isolate" and "active ingredient" indicated differences in sensitivity among the tested isolates to used active ingredients. Significant differences $(p<0.05)$ among the relative diameters of distinct $H$. pseudoalbidus isolates were found on thiram- and chlorothalonil-amended medium (Tab. 3), with isolate ZLVG 213 being the most sensitive to thiram and isolate ZLVG 200 being the most sensitive to chlorothalonil.

\section{Effect of urea on in vitro growth of $H$. pseudoalbidus mycelium}

Significant differences $(\mathrm{F}=47.84 ; \mathrm{p}<0.001)$ were found among the relative diameters of H. pseudoalbidus cultures treated with different concentrations of urea. The lowest urea concentration $(0.5 \mathrm{~g} / \mathrm{l})$ has slightly (non-significant difference, $\mathrm{p}<0.05)$ enhanced the growth of three of the four tested H. pseudoalbidus isolates as compared to control plates (Tab. 3). The highest urea concentrations $(2.5,5.0$ and $10.0 \mathrm{~g} / \mathrm{l})$ have significantly $(p<0.05)$ reduced the mycelial growth as compared to control plates (Tab. 3).

Significant differences $(F=9.30 ; p<0.001)$ in sensitivity to urea were also observed among different $H$. pseudoalbidus isolates (Tab. 3). The isolate ZLVG 200 was the least susceptible to urea; only the highest urea concentration $(10.0 \mathrm{~g} / \mathrm{l})$ caused a significant (at $\mathrm{p}<0.05)$ reduction in its growth compared to controls. ZLVG 213 was the most sensitive isolate which growth was significantly $(p<0.05)$ reduced already at urea concentration as low as $1.0 \mathrm{~g} / \mathrm{l}$ (Tab. 3 ).

\section{Effect of fungicides on formation of $H$. pseudoalbidus apothecia}

Apothecia of $H$. pseudoalbidus were formed on $97 \%$ of the control petioles with a mean density of 3.84 fruiting bodies per $\mathrm{cm}$ of a petiole. All fungicidal treatments negatively affected the occurrence of apothecia (Tab. 4), although the efficacy of different active ingredients was significantly different $(\mathrm{F}=2.53 ; \mathrm{p}=0.03)$.

Carbendazim was the only active ingredient which has completely prevented the apothecia formation (at the highest tested concentration - $10.0 \mathrm{mg} / \mathrm{l})$. Similar efficacy was observed at a concentration of $1.0 \mathrm{mg} / \mathrm{l}$, as only a few apothecia developed. The lower two carbendazim concentrations $(0.01$ and $0.1 \mathrm{mg} / \mathrm{l})$ did not significantly $(\mathrm{p}<0.05)$

Tab. 3 - Relative colony diameter (mean $\pm \mathrm{SE}$ ) of 14-day old Hymenoscyphus pseudoalbidus cultures on PDA growth media amended with three different concentrations of five different fungicides (Tab. 2) and five different concentrations of urea. Relative colony diameters were calculated by dividing mean diameter of every colony of a particular isolate on fungicide- and urea-amended plate by mean colony diameter of the same isolate on control plates. Within lines, values labelled with different lowercase letters are significantly different ( $<<0.05)$; (n.s.): no significant difference at $\mathrm{p}<0.05$ (Games-Howell test - Quinn \& Keough 2002). Within columns, the significance of differences is indicated with uppercase letters.

\begin{tabular}{|c|c|c|c|c|c|c|}
\hline $\begin{array}{l}\text { Active } \\
\text { ingredients }\end{array}$ & Conc. & $\begin{array}{l}\text { Isolate } \\
\text { ZLVG } 176\end{array}$ & $\begin{array}{l}\text { Isolate } \\
\text { ZLVG } 177\end{array}$ & $\begin{array}{l}\text { Isolate } \\
\text { ZLVG } 200\end{array}$ & $\begin{array}{l}\text { Isolate } \\
\text { ZLVG } 213\end{array}$ & Mean \\
\hline Captan & $0.1 \mathrm{mg} / 1$ & $1.04 \pm 0.04$ n.s. A & $1.12 \pm 0.08$ n.s. A & $1.13 \pm 0.10$ n.s. A & $1.16 \pm 0.10$ n.s. A & $1.11 \pm 0.09 \mathrm{~A}$ \\
\hline Thiram & & $1.09 \pm 0.12 \mathrm{a} \mathrm{A}$ & $0.96 \pm 0.05 \mathrm{ab} \mathrm{B}$ & $0.87 \pm 0.07 \mathrm{~b} \mathrm{~B}$ & $0.74 \pm 0.05$ c B & $0.92 \pm 0.15 \mathrm{~B}$ \\
\hline Chlorotalonil & & $0.80 \pm 0.12$ a B & $0.84 \pm 0.12 \mathrm{a} \mathrm{B}$ & $0.93 \pm 0.19 \mathrm{a} \mathrm{AB}$ & $0.13 \pm 0.01 \mathrm{~b} \mathrm{C}$ & $0.68 \pm 0.35 \mathrm{~B}$ \\
\hline Prochloraz & & $0 \pm 0 \mathrm{~b} \mathrm{C}$ & $0.08 \pm 0.03 \mathrm{a} \mathrm{C}$ & $0.02 \pm 0.00 \mathrm{~b} \mathrm{C}$ & $0.06 \pm 0.00 \mathrm{~b} \mathrm{D}$ & $0.04 \pm 0.04 \mathrm{C}$ \\
\hline Carbendazim & & $0 \pm 0$ n.s. $\mathrm{C}$ & $0 \pm 0$ n.s. D & $0 \pm 0$ n.s. D & $0 \pm 0$ n.s. E & $0 \pm 0 \mathrm{D}$ \\
\hline Captan & $1.0 \mathrm{mg} / 1$ & $1.07 \pm 0.08$ n.s. A & $1.10 \pm 0.23$ n.s. A & $1.11 \pm 0.08$ n.s. A & $1.12 \pm 0.17$ n.s. A & $1.10 \pm 0.14 \mathrm{~A}$ \\
\hline Thiram & & $0.76 \pm 0.11 \mathrm{~b} \mathrm{~B}$ & $0.95 \pm 0.03 \mathrm{a} \mathrm{A}$ & $0.15 \pm 0.08$ с B & $0.59 \pm 0.09 \mathrm{~b} \mathrm{~B}$ & $0.61 \pm 0.31 \mathrm{~B}$ \\
\hline Chlorotalonil & & $0.17 \pm 0.17$ n.s. $\mathrm{C}$ & $0.19 \pm 0.13$ n.s. $B$ & $0.21 \pm 0.23$ n.s. $\mathrm{B}$ & $0.03 \pm 0.01$ n.s. $\mathrm{C}$ & $0.15 \pm 0.16 \mathrm{C}$ \\
\hline Prochloraz & & $0 \pm 0$ n.s. $\mathrm{C}$ & $0.02 \pm 0.02$ n.s. B & $0.01 \pm 0.01$ n.s. $\mathrm{B}$ & $0.02 \pm 0.02$ n.s. $\mathrm{CD}$ & $0.01 \pm 0.02 \mathrm{D}$ \\
\hline Carbendazim & & $0 \pm 0$ n.s. $\mathrm{C}$ & $0 \pm 0$ n.s. $\mathrm{B}$ & $0 \pm 0$ n.s. $B$ & $0 \pm 0$ n.s. $\mathrm{D}$ & $0 \pm 0 \mathrm{D}$ \\
\hline Captan & $10.0 \mathrm{mg} / 1$ & $0.91 \pm 0.12$ n.s. A & $0.84 \pm 0.20$ n.s. A & $0.79 \pm 0.06$ n.s. A & $0.81 \pm 0.13$ n.s. A & $0.84 \pm 0.13 \mathrm{~A}$ \\
\hline Thiram & & $0.20 \pm 0.19$ bc B & $0.54 \pm 0.03 \mathrm{a} \mathrm{A}$ & $0.01 \pm 0.01 \mathrm{c} \mathrm{B}$ & $0.10 \pm 0.01 \mathrm{~b} \mathrm{~B}$ & $0.21 \pm 0.22 \mathrm{~B}$ \\
\hline Chlorotalonil & & $0.01 \pm 0.02 \mathrm{~b} \mathrm{~B}$ & $0.11 \pm 0.03 \mathrm{a} \mathrm{B}$ & $0.04 \pm 0.03 \mathrm{~b} \mathrm{~B}$ & $0 \pm 0 \mathrm{~b} \mathrm{C}$ & $0.04 \pm 0.05 \mathrm{C}$ \\
\hline Prochloraz & & $0 \pm 0$ n.s. B & $0 \pm 0$ n.s. $\mathrm{C}$ & $0 \pm 0$ n.s. B & $0 \pm 0$ n.s. $\mathrm{C}$ & $0 \pm 0 \mathrm{D}$ \\
\hline Carbendazim & & $0 \pm 0$ n.s. B & $0 \pm 0$ n.s. $\mathrm{C}$ & $0 \pm 0$ n.s. B & $0 \pm 0$ n.s. $\mathrm{C}$ & $0 \pm 0 \mathrm{D}$ \\
\hline \multirow[t]{5}{*}{ Urea } & $0.5 \mathrm{~g} / 1$ & $1.07 \pm 0.03 \mathrm{a} \mathrm{A}$ & $1.20 \pm 0.19 \mathrm{ab} \mathrm{A}$ & $1.23 \pm 0.07 \mathrm{a} \mathrm{A}$ & $0.78 \pm 0.03 \mathrm{~b} \mathrm{~A}$ & $1.07 \pm 0.06 \mathrm{~A}$ \\
\hline & $1.0 \mathrm{~g} / 1$ & $0.33 \pm 0.07 \mathrm{c} \mathrm{B}$ & $1.05 \pm 0.21 \mathrm{abc} A B$ & $1.20 \pm 0.06 \mathrm{a} \mathrm{A}$ & $0.78 \pm 0.06 \mathrm{~b} \mathrm{~A}$ & $0.84 \pm 0.09 \mathrm{AB}$ \\
\hline & $2.5 \mathrm{~g} / 1$ & $0.14 \pm 0.03 \mathrm{~b} \mathrm{~B}$ & $0.69 \pm 0.12 \mathrm{a} \mathrm{AB}$ & $0.97 \pm 0.02 \mathrm{a} \mathrm{A}$ & $0.58 \pm 0.10 \mathrm{a} A B$ & $0.60 \pm 0.08 \mathrm{BC}$ \\
\hline & $5.0 \mathrm{~g} / 1$ & $0.07 \pm 0.01 \mathrm{c} \mathrm{B}$ & $0.40 \pm 0.08$ bc AB & $0.78 \pm 0.03 \mathrm{a} \mathrm{B}$ & $0.14 \pm 0.01 \mathrm{~b} \mathrm{BC}$ & $0.35 \pm 0.07 \mathrm{CD}$ \\
\hline & $10.0 \mathrm{~g} / 1$ & $0.06 \pm 0.01 \mathrm{~b} \mathrm{~B}$ & $0.17 \pm 0.05 \mathrm{ab} B$ & $0.37 \pm 0.01 \mathrm{a} \mathrm{C}$ & $0.05 \pm 0.02 \mathrm{~b} \mathrm{C}$ & $0.16 \pm 0.03 \mathrm{D}$ \\
\hline
\end{tabular}


Tab. 4 - Number and mean disc area $\left(\mathrm{mm}^{2}\right)$ of Hymenoscyphus pseudoalbidus apothecia developed per $\mathrm{cm}$ of ash petioles after the 24-hour treatments in solutions with different concentrations of five different fungicides (Tab. 2) and in sterile distilled water in case of control. Counting and measurements were done 34 days after the treatments. Mean values \pm standard error are reported. Within lines, values labelled with different lowercase letters are significantly different $(\mathrm{p}<0.05)$; (n.s.): non significant $(\mathrm{p}>0.05$; Games-Howell test - Quinn \& Keough 2002). Within columns, the significance of differences is indicated with uppercase letters.

\begin{tabular}{|c|c|c|c|c|c|c|c|}
\hline \multirow{2}{*}{ Parameter } & \multirow{2}{*}{$\begin{array}{l}\text { Conc. } \\
\text { (mg/l) }\end{array}$} & \multicolumn{5}{|c|}{ Active ingredients of respective fungicides } & \multirow{2}{*}{ Control } \\
\hline & & Captan & Thiram & Chlorothalonil & Prochloraz & Carbendazim & \\
\hline \multirow{5}{*}{$\begin{array}{l}\text { Number of } \\
\text { apothecia per } \\
\text { cm of ash } \\
\text { petioles }\end{array}$} & 0.01 & Not tested & Not tested & Not tested & $2.55 \pm 0.26 \mathrm{~b} \mathrm{~A}$ & $3.15 \pm 0.42 \mathrm{ab} \mathrm{A}$ & $3.84 \pm 0.39 \mathrm{a}$ \\
\hline & 0.1 & $3.20 \pm 0.30$ ab n.s. & $3.37 \pm 0.32 \mathrm{ab} A$ & $3.09 \pm 0.43 \mathrm{ab} A$ & $2.17 \pm 0.29 \mathrm{~b} \mathrm{~A}$ & $2.51 \pm 0.27 \mathrm{ab} \mathrm{A}$ & $3.84 \pm 0.39 \mathrm{a}$ \\
\hline & 1.0 & $3.28 \pm 0.37$ a n.s. & $2.76 \pm 0.38 \mathrm{ab} \mathrm{AB}$ & $2.55 \pm 0.35 \mathrm{ab} \mathrm{AB}$ & $1.71 \pm 0.25 \mathrm{~b} \mathrm{~A}$ & $0.05 \pm 0.02 \mathrm{c} \mathrm{B}$ & $0.39 \mathrm{a}$ \\
\hline & 10 & $2.41 \pm 0.34$ ab n.s. & $1.83 \pm 0.35 \mathrm{bc} \mathrm{BC}$ & $2.02 \pm 0.32 \mathrm{~b} \mathrm{AB}$ & $0.76 \pm$ & $.00 \mathrm{~d} \mathrm{~B}$ & $.39 \mathrm{a}$ \\
\hline & 100 & $2.29 \pm 0.35$ b n.s. & $1.37 \pm 0.26 \mathrm{~b} \mathrm{C}$ & $1.51 \pm$ & Not & & $3.84 \pm 0.39 \mathrm{a}$ \\
\hline \multirow{5}{*}{$\begin{array}{l}\text { Mean disc } \\
\text { area of } \\
\text { apothecia per } \\
\text { cm of ash } \\
\text { petioles }\end{array}$} & 0.01 & Not tested & Not tested & Not tes & $0.44 \mathrm{~b} \mathrm{~A}$ & 9.56 & $6.46 \pm 0.66 \mathrm{a}$ \\
\hline & 0.1 & $6.21 \pm 0.57$ ab n.s. & $6.17 \pm 0.58 \mathrm{ab} \mathrm{A}$ & $8.41 \pm 1.17 \mathrm{ab} \mathrm{A}$ & $5.61 \pm 0.74 \mathrm{~b} \mathrm{~A}$ & $9.56 \pm 1.02 \mathrm{a} \mathrm{A}$ & $6.46 \pm 0.66 \mathrm{ab}$ \\
\hline & 1.0 & $6.33 \pm 0.71$ a n.s. & $4.51 \pm 0.62 \mathrm{a} \mathrm{AB}$ & $4.01 \pm 0.55 \mathrm{a} \mathrm{B}$ & $4.15 \pm 0.60 \mathrm{a} A B$ & $0.47 \pm 0.19 \mathrm{~b} \mathrm{~B}$ & $6.46 \pm 0.66 \mathrm{a}$ \\
\hline & 10 & $6.87 \pm 0.97$ a n.s. & $4.40 \pm 0.83 \mathrm{ab} \mathrm{AB}$ & $5.66 \pm 0.89 \mathrm{a} A B$ & $2.17 \pm 0.40 \mathrm{~b} \mathrm{~B}$ & $0.00 \pm 0.00 \mathrm{c} \mathrm{B}$ & $6.46 \pm 0.66 \mathrm{a}$ \\
\hline & 100 & $5.62 \pm 0.85$ ab n.s. & $3.28 \pm 0.63 \mathrm{~b} \mathrm{~B}$ & $3.92 \pm 0.77 \mathrm{ab} \mathrm{B}$ & Not tested & Not tested & $6.46 \pm 0.66 \mathrm{a}$ \\
\hline
\end{tabular}

affect the apothecia formation (Tab. 4). At concentrations of $0.1,1.0$ and $10.0 \mathrm{mg} / \mathrm{l}$, prochloraz has significantly $(\mathrm{p}<0.05)$ reduced the occurrence of apothecia as compared to the control treatment (Tab. 4). However, even at the highest tested concentration of this active ingredient $(10 \mathrm{mg} / \mathrm{l})$ the fungus was still able to form 0.76 apothecia $/ \mathrm{cm}$. Chlorothalonil, thiram and captan were even less effective (Tab. 4). Concentrations of these three active ingredients as high as 100 $\mathrm{mg} / \mathrm{l}$ did not reduce the number of developed fruit bodies below 1 per $\mathrm{cm}$ of a petiole.

Treatments with all tested active ingredients of proper concentration did reduce the occurrence of developed apothecia, but at the same time often positively affected apothecial disc size (Tab. 4). The mean apothecial disk area on the control petioles was $6.46 \mathrm{~mm}^{2} / \mathrm{cm}$, while it exceeded $8 \mathrm{~mm}^{2} / \mathrm{cm}$

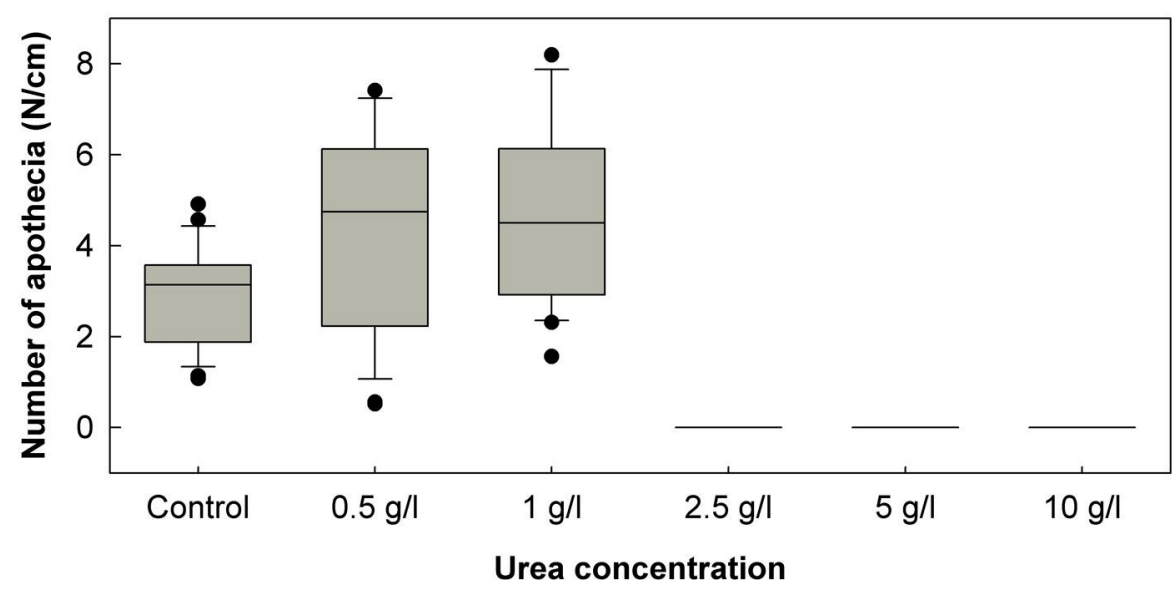

Fig. 1 - Number of Hymenoscyphus pseudoalbidus apothecia developed per $\mathrm{cm}$ of ash leaf petioles treated with urea of five different concentrations. The box plots show the $10^{\text {th }}$ percentile (bottom end of the whisker), the first quartile (bottom of the box), the median (line inside the box), the third quartile (top of the box) and the $90^{\text {th }}$ percentile (top end of the whisker). on petioles treated with $0.1 \mathrm{mg} / \mathrm{l}$ of chlorothalonil and reached $9.56 \mathrm{~mm}^{2} / \mathrm{cm}$ on petioles treated with the two lowest $(0.01$ and $0.1 \mathrm{mg} / \mathrm{l})$ concentrations of carbendazim (Tab. 4). However, the differences were not significant $(\mathrm{p}<0.05)$. Compared to controls, the mean area of apothecial discs was significantly $(\mathrm{p}<0.05)$ reduced only by the highest tested carbendazim concentrations $(1.0$ and $10 \mathrm{mg} / \mathrm{l})$ and the highest prochloraz (10 $\mathrm{mg} / \mathrm{l})$ and thiram $(100 \mathrm{mg} / \mathrm{l})$ concentrations (Tab. 4).

\section{Effect of urea on formation of \\ H. pseudoalbidus apothecia}

In the January 2011 experiment, treatment of petioles with any of the three tested urea concentrations $(5,10$ and $20 \mathrm{~g} / \mathrm{l})$ completely prevented the formation of $H$. pseudoalbidus apothecia. Urea concentrations of 5 and 10 $\mathrm{g} / \mathrm{l}$ again proved to be fully effective in the prevention of apothecia formation in the April 2011 experiment, and no apothecia were formed on petioles treated with a lower urea concentration $(2.5 \mathrm{~g} / \mathrm{l})$. However, the two lowest urea concentrations $(0.5$ and 1.0 g/l) in the April 2011 experiment have positively affected the formation of apothecia (Fig. 1). The mean number of apothecia formed per $\mathrm{cm}$ of the control leaf petioles was 2.86 , while on petioles treated with urea of 0.5 and $1.0 \mathrm{~g} / 1$ concentration, the number of apothecia was significantly $(\mathrm{p}<0.05)$ higher: 5.28 and 4.84 pieces $/ \mathrm{cm}$, respectively. Approximately in two weeks after these treatments, other fungi started to intensively overgrow urea-treated ash leaf petioles. Among these fungi, Fusarium species were the most common, and coprinoid fungi were also often observed.

\section{Discussion}

The mycelial growth in pure culture and development of $H$. pseudoalbidus apothecia on ash leaf petioles were the most effectively inhibited by carbendazim (methyl benzimidazol-2-ylcarbamate). This active ingredient belongs to a group of benzimidazole fungicides, which subsequently binds to spindle microtubules and blocks mitosis and cell division. By binding to cytoplasmic microtubules, benzimidazole fungicides also affect fungal tip growth (Deacon 2006). Growth of $H$. pseudoalbidus in pure culture was inhibited also by prochloraz, an imidazole fungicide that binds to demethylase enzyme and inhibits normal sterol synthesis (Deacon 2006). Both carbendazim and prochloraz therefore bind to specific component of fungal cell, and fungi often develop resistance against such substances (Deacon 2006).

The development of resistance of a fungus against fungicides can be avoided by a proper application strategy, which involves the 
alternating use of fungicides with different modes of action, or the combining use of systemic and broad-spectrum protectant fungicides (Deacon 2006). Of the broad-spectrum protectant fungicides tested in our experiments, $H$. pseudoalbidus seems to be the most sensitive to products containing chlorothalonil and thiram. A combination of carbendazim and chlorothalonil very effectively inhibited growth of Gremmeniella abietina (Santamaría et al. 2007), a fungus classified in the Helotiales order which also includes the ash dieback pathogen. We assume that this combination may also be efficient for the control of the ash dieback; however, further testing is needed to confirm the effectiveness under field conditions.

Following the infection, H. pseudoalbidus quickly and extensively colonizes different host tissues (Schumacher et al. 2010, Dal Maso et al. 2012, Cleary et al. 2013) and becomes very difficult to suppress (Cooke et al. 2013). Therefore, preventive treatments to protect healthy trees against the infection may prove to be more appropriate. Because H. pseudoalbidus infects trees mainly through the leaves (Cleary et al. 2013, Gross et al. 2014), fungicide applications should in the first instance protect the leaf surface. Relatively long sporulation period of the pathogen (Kirisits et al. 2009, Timmermann et al. 2011, Kowalski et al. 2013) would require regular use of the fungicides to ensure the protection. Due to negative impacts of fungicides on the environment, this could be justified for the protection of individual highvalue trees but not for usage in forest stands. Fungicides could also be used in forest nurseries that produce ash seedlings, although such treatments would make sense only if the treated plants would be outplanted in disease-free areas. Additionally, fungicide treatments might only prevent symptom development (Gross et al. 2014) posing the risk of transportation of latent infected plants to disease-free areas. However, 10-hour water heat treatments of $F$. excelsior saplings at 36 or $40{ }^{\circ} \mathrm{C}$ seem to eradicate the pathogen inside the ash tissue (Hauptman et al. 2013). With lower negative impact to the environment, water heat treatment of ash saplings before their transportation is probably more appropriate option for the disease control than chemical treatment.

Pyrimethanil, iprodione and fenhexamid did not show promising results in the preliminary testing and were excluded from the main experiment; however their potential in preventive leaf protection could not be neglected. Pyrimethanil is an inhibitor of methionine biosynthesis and consequently inhibits secretion of enzymes necessary for infection, and iprodione and fenhexamid affect initial fungal development phases, namely spore germination and germ tube elongation (Tomlin 2003). We hypothesize that these chemicals could show better results if spore suspension has been used for the inoculation of fungicide-amended plates instead of mycelium (agar plugs). Therefore, we suggest to include those active ingredients in further research, especially aiming at checking their efficiency in prevention of leaf infections.

In infected areas, numerous apothecia develop on fallen ash leaf petioles. In some areas, more than $95 \%$ of the petioles can be infected, and more than 1000 apothecia per square meter can be counted at a time (Kowalski et al. 2013). In the present study, the apothecia developed on $97 \%$ of the control petioles. Cooke et al. (2013) hypothesized that benzimidazole-based fungicides (carbendazim, thiabendazole) could efficiently reduce sporulation of the pathogen as they are persistent and antisporulant; however, pseudosclerotia formed on the fallen leaf petioles by $H$. pseudoalbidus are likely resistant to the benzimidazole treatments. In our tests, petiole treatment with $10 \mathrm{mg} / \mathrm{l}$ carbendazim did prevent formation of the apothecia, although it remains unknown whether the fungus has completely been disabled by this treatment. Further experiments are needed to examine effect of chemical treatments on the survival of $H$. pseudoalbidus inside the pseudosclerotia.

If the pathogen is not suppressed by the fungicides, multiple repetitions of the treatment should follow to prevent its sporulation. On the other hand, in their review Cooke et al. (2013) pointed out that pseudosclerotial stage of the fungus could be eliminated by a quaternary ammonium biocide. Moreover, treatments that prevent formation of the apothecia and accelerate degradation of the substrate on which apothecia develop could serve as an alternative option. According to the results of our experiments, urea treatment may be one of the best options. It is known that urea treatment inhibits development of certain fungal pathogens by producing ammonia, which is released upon urea hydrolysis, and/or by elevating $\mathrm{pH}$ values in the treated substrate (Johansson et al. 2002, Green et al. 2006). However, urea itself can also be toxic to fungal pathogens (Veverka et al. 2007). Furthermore, urea applications stimulate the activity of some antagonistic and saprotrophic microorganisms (Bengtsson et al. 2006, Green et al. 2006, Veverka et al. 2007). The latter are responsible for accelerated break down of the treated substrate.

Our experiments showed that effective concentrations of urea inhibit in vitro growth of H. pseudoalbidus and formation of its apothecia. We did not investigate if this inhibition is a result of urea itself, if it is caused by released ammonia or by increased $\mathrm{pH}$ values. However, it was clearly demonstrated that urea treatments may strongly affect the ba- lance between $H$. pseudoalbidus and other fungi in favor of the latter. Based on visual observations of the fruiting structures, $H$. pseudoalbidus was a dominant fungal species on control petioles, while no apothecia of the ash dieback pathogen emerged on petioles treated with urea at concentrations of $2.5 \mathrm{~g} / 1$ or higher. Instead, numerous other fungi appeared: the petioles were most often covered by mycelia of different Fusarium species, and fruiting bodies of coprinoid fungi were also commonly observed. It is known that urea treatments do positively affect also occurrence of other microorganisms (e.g., bacteria), which are important actors in the leaf degradation processes (Green et al. 2006).

Our results also indicated the importance of usage of appropriate urea and fungicide concentrations. For example, low urea concentrations have positively affected the formation of $H$. pseudoalbidus apothecia (Fig. 1). The tested fungicides of low concentrations did not increase the density of apothecia on the treated petioles (Tab. 4), but in some cases have positively affected disk area of the developed apothecia (Tab. 4). Urea solutions of 2.5 and $5 \%$ are used in practice for treatment of apple and cherry leaves against the infections by Venturia inaequalis (Cooke) G. Winter and Blumeriella jaapii (Rehm) Arx, respectively (Sutton et al. 2000, Green et al. 2006). Decomposition of cherry leaf litter after the treatment with the $2.5 \%$ urea solution proved to be even more accelerated than after treatment with the 5\% urea solution (Green et al. 2006). Our observations led to a similar conclusion: ash leaf petioles treated with urea at a concentration of $5 \mathrm{~g} / \mathrm{l}$ were more intensively overgrown by other fungi than petioles treated with urea at a concentration of $10 \mathrm{~g} / \mathrm{l}$.

Efficacy of the tested fungicides and urea at different concentrations needs to be further investigated under field conditions, including also additional factors such as timing of the treatments. On the other hand, search for environmentally friendly alternatives to herein investigated chemical treatments should be considered. Ecospray, a garlic extract known to be effective against a range of organisms, could be one of the interesting options (Cooke et al. 2013).

In cases of apple scab and cherry leaf spot disease, application of some biocontrol agents showed efficiency similar to that of urea treatments (Carisse et al. 2000, Bengtsson et al. 2006). Other fungi isolated from ash tissues showed some antagonistic effect against H. pseudoalbidus (Kowalski \& Holdenrieder 2009, Kowalski \& Bartnik 2010, Gross et al. 2014), and these fungi could possibly act as biocontrol agents in natural conditions as well. Interestingly, during our experiments, fungus gnats from the Sciaridae family were found to be feeding on $H$. 
pseudoalbidus apothecia; however, there is little evidence that these insects could significantly affect the reproductive potential of the pathogen in nature.

\section{Concluding remarks}

Because of the wide distribution and high infection potential of the pathogen, and due to negative impacts of fungicides on the environment, the possibilities of fungicide application for the control of ash dieback are rather limited. In our experiments, carbendazim has inhibited growth of the pathogen in pure culture and clearly restricted formation of $H$. pseudoalbidus apothecia. Based on this we hypothesize that this compound may also suppress growth and reproduction of the pathogen under the field conditions.

Treatment of infected ash leaf debris to prevent sporulation of $H$. pseudoalbidus seems to be one of the most effective control measures. Our results indicate that infection potential of the pathogen could be significantly reduced with the use of urea. Urea acts directly on the fungus, but also stimulates the activity of antagonistic microorganisms and occurrence and reproduction of saprophytic fungi. The later accelerate degradation of the treated leaf debris. Therefore, the application of urea for treatment of infected ash leaf debris could be even more effective than the use of fungicides. Moreover, it is also cost-effective and environmentally friendly.

To reveal the actual efficacy of chemicals used in our research, further experiments under field conditions are required. Nevertheless, more environmentally friendly options for ash dieback control should be studied simultaneously.

\section{Acknowledgements}

This study was financed by the Slovenian Research Agency and the Ministry of Agriculture and Environment of the Republic of Slovenia through research project L4-2301 and research program $\mathrm{P} 4-0107$. The authors would like to thank two anonymous reviewers for their constructive suggestions, which have greatly improved the paper.

\section{References}

Bengtsson M, Green H, Leroul N, Pedersen HL, Hockenhull J (2006). Effect of autumn application of urea on saprotrophic fungi in off-season leaf litter of sour cherry and evaluation of fungal isolates to reduce primary inoculum of Blumeriella jaapii. Journal of Plant Diseases and Protection 113: 107-112. [online] URL: http://orgprints.org/9991/

Carisse O, Philion V, Rolland D, Bernier J (2000). Effect of fall application of fungal antagonists on spring ascospore production of the apple scab pathogen, Venturia inaequalis. Phytopathology 90: 31-37. - doi: 10.1094/PHYTO.2000.90.1.31 Cleary MR, Daniel G, Stenlid J (2013). Light and scanning electron microscopy studies of the early infection stages of Hymenoscyphus pseudoalbidus on Fraxinus excelsior. Plant Pathology 62 (6): 1294-1301. - doi: 10.1111/ppa.2013.62.issue-6

Cooke L, Fleming C, McCracken A (2013). Efficacy of biocides, disinfectants and other treatments to limit the spread of ash dieback caused by Chalara fraxinea. Agri-Food and Bioscience Institute, pp. 37. [online] URL: http://www.afbini.gov.uk/efficacy_of_biocides_and_disinfectants_on_chalara_fraxinea_24_may_2013.pdf Dal Maso E, Fanchin G, Mutto Accordi S, Scattolin L, Montecchio L (2012). Ultrastructural modifications in Common ash tissues colonised by Chalara fraxinea. Phytopathologia Mediterranea 51: 599-606. [online] URL: http://www.fupress.net/index.php/pm/article/view/11132

Deacon JW (2006). Fungal Biology. Blackwell Publishing, Malden, USA, pp. 371.

Drenkhan R, Hanso M (2010). New host species for Chalara fraxinea. New Disease Reports 22: 16. - doi: 10.5197/j.2044-0588.2010.022

Green H, Bengtsson M, Duval X, Pedersen HL, Hockenhull J, Larsen J (2006). Influence of urea on the cherry leaf spot pathogen, Blumeriella jaapii, and on microorganisms in decomposing cherry leaves. Soil Biology and Biochemistry 38: 2731-2742. - doi: 10.1016/j.soilbio.2006.04.027 Gross A, Zaffarano PL, Duo A, Grünig CR (2012). Reproductive mode and life cycle of the ash dieback pathogen Hymenoscyphus pseudoalbidus. Fungal Genetics and Biology 49: 977-986. - doi: 10.1016/j.fgb.2012.08.008

Gross A, Holdenrieder O, Pautasso M, Queloz V, Sieber TN (2014). Hymenoscyphus pseudoalbidus, the causal agent of European ash dieback. Molecular Plant Pathology 15: 5-21. - doi: 10.11 11/mpp. 12073

Hauptman T, Piškur B, de Groot M, Ogris N, Ferlan M, Jurc D (2013). Temperature effect on Chalara fraxinea: heat treatment of saplings as a possible disease control method. Forest Pathology 43 (5): 360-370. - doi: 10.1111/efp.12038 Johansson SM, Pratt JE, Asiegbu FO (2002). Treatment of Norway spruce and Scots pine stumps with urea against the root and butt rot fungus Heterobasidion annosum - possible modes of action. Forest Ecology and Management 157: 87-100. - doi: 10.1016/S0378-1127(00)006 61-7

Kirisits T, Matlakova M, Mottinger-Kroupa S, Cech T, Halmschlager E (2009). The current situation of ash dieback caused by Chalara fraxinea in Austria. In: Proceedings of the "IUFRO Working party 7.02.02" (Dogmus-Lehtijärvi T eds). Egirdir (Turkey) 11-16 May 2009. Süleyman Demirel University, SDU Faculty of Forestry Journal, Special Issue, pp. 97-119.

Kirisits T, Matlakova M, Mottinger-Kroupa S, Halmschlager E, Lakatos F (2010). Chalara fraxinea associated with dieback of narrow-leafed ash (Fraxinus angustifolia). Plant Pathology 59: 411. - doi: 10.1111/j.1365-3059.2009.02162.x Kowalski T (2006). Chalara fraxinea sp. nov. associated with dieback of ash (Fraxinus excel- sior) in Poland. Forest Pathology 36: 264-270. doi: 10.1111/j.1439-0329.2006.00453.x

Kowalski T, Bartnik C (2010). Morphological variation in colonies of Chalara fraxinea isolated from ash (Fraxinus excelsior L.) stems with symptoms of dieback and effects of temperature on colony growth and structure. Acta Agrobotanica 63: 99-106. - doi: 10.5586/aa.2010.012

Kowalski T, Bialobrzeski M, Ostafinska A (2013). The occurrence of Hymenoscyphus pseudoalbidus apothecia in the leaf litter of Fraxinus excelsior stands with ash dieback symptoms in southern Poland. Acta Mycologica 48: 135-146. - doi: 10.5586/am.2013.031

Kowalski T, Holdenrieder O (2009). Pathogenicity of Chalara fraxinea. Forest Pathology 39: 1-7. doi: 10.1111/j.1439-0329.2008.00565.x

Pautasso M, Aas G, Queloz V, Holdenrieder O (2013). European ash (Fraxinus excelsior) dieback - a conservation biology challenge. Biological Conservation 158: 37-49. - doi: 10.1016/j.biocon.2012.08.026

Queloz V, Grünig CR, Berndt R, Kowalski T, Sieber TN, Holdenrieder O (2011). Cryptic speciation in Hymenoscyphus albidus. Forest Pathology 41: 133-142. - doi: 10.1111/j.1439$0329.2010 .00645 . x$

Quinn G, Keough M (2002). Experimental design and data analysis for biologists. Cambridge University Press, Cambridge, UK, pp. 537. [online] URL: http://books.google.it/books?id=VtU3-y7L aLYC

R Development Core Team (2011). R: a language and environment for statistical computing. $\mathrm{R}$ Foundation for Statistical Computing, Vienna, Austria. [online] URL: http://www.R-project.org/ Santamaría O, González MA, Pajares JA, Diez JJ (2007). Effect of fungicides, endophytes and fungal filtrates on in vitro growth of Spanish isolates of Gremmeniella abietina. Forest Pathology 37: 251-262. - doi: 10.1111/j.1439-0329.20 07.00498.x

Schumacher J, Kehr R, Leonhard S (2010). Mycological and histological investigations of Fraxinus excelsior nursery saplings naturally infected by Chalara fraxinea. Forest Pathology 40: 419429. - doi: 10.1111/j.1439-0329.2009.00615.x Sutton DK, MacHardy WE, Lord WG (2000). Effects of shredding or treating apple leaf litter with urea on ascospore dose of Venturia inaequalis and disease buildup. Plant Disease 84: 1319-1326. - doi: 10.1094/PDIS.2000.84.12. 1319

Timmermann V, Børja I, Hietala AM, Kirisits T, Solheim H (2011). Ash dieback: pathogen spread and diurnal patterns of ascospore dispersal, with special emphasis on Norway. EPPO Bulletin 41: 14-20. - doi: 10.1111/j.1365-2338.2010.02429.x Tomlin CDS (2003). The pesticide manual: a world compendium. British Crop Protection Council, Hampshire, UK, pp. 1344.

Veverka K, Stolcova J, Ruzek P (2007). Sensitivity of fungi to urea, ammonium nitrate and their equimolar solution UAN. Plant Protection Science 43 (4): 157-164. [online] URL: http://agris.- 
fao.org/agris-search/search.do? recordID $=\mathrm{CZ20}$ 08000274

Zhao YJ, Hosoya T, Baral HO, Hosaka K, Kakishima M (2012). Hymenoscyphus pseudoal- bidus, the correct name for Lambertella albida reported from Japan. Mycotaxon 122: 25-41. doi: $10.5248 / 122.25$

Zuur A, Ieno EN, Walker N, Savelie AA, Smith
GM (2009). Mixed effect models and extensions in ecology with R. Springer, New York, USA, pp. 596. [online] URL: http://books.google.com/ books?id=vQUNprFZKHsC 